\title{
Long-term population trends of the lesser horseshoe bat Rhinolophus hipposideros and the greater mouse-eared bat Myotis myotis in Poland
}

Andrzej Węgiel ( $\sim$ wegiel@up.poznan.pl)

Poznań University of Life Sciences, Faculty of Forestry and Wood Technology

\section{Witold Grzywiński}

Poznań University of Life Sciences, Faculty of Forestry and Wood Technology

Jakub Z. Kosicki

Adam Mickiewicz University, Faculty of Biology, Department of Avian Biology \& Ecology

Piotr Tryjanowski

Poznań University of Life Sciences, Institute of Zoology

Jakub Nowak

Cracow Caving Club

Jolanta Węgiel

Poznań University of Life Sciences, Faculty of Forestry and Wood Technology

\section{Research Article}

Keywords: pesticides, heavy metals, human pressure, TRIM methods, Rhinolophus hipposideros , Myotis myotis

Posted Date: February 23rd, 2021

DOl: https://doi.org/10.21203/rs.3.rs-234666/v1

License: (9) This work is licensed under a Creative Commons Attribution 4.0 International License. Read Full License

Version of Record: A version of this preprint was published at The European Zoological Journal on December 3rd, 2021. See the published version at https://doi.org/10.1080/24750263.2021.2006324. 


\title{
Long-term population trends of the lesser horseshoe bat Rhinolophus hipposideros and the greater mouse- eared bat Myotis myotis in Poland
}

\author{
Andrzej Węgiel ${ }^{1, *}$, Witold Grzywiński ${ }^{1}$, Jakub Z. Kosicki ${ }^{2}$, Piotr Tryjanowski ${ }^{3,4}$, Jakub Nowak ${ }^{5}$ \\ \& Jolanta Węgiel ${ }^{1}$ \\ ${ }^{1}$ Faculty of Forestry and Wood Technology, Poznań University of Life Sciences, Wojska Polskiego 28, \\ 60-637 Poznań, Poland \\ ${ }^{2}$ Department of Avian Biology \& Ecology, Faculty of Biology, Adam Mickiewicz University, Umultowska \\ 89, 61-614 Poznań, Poland \\ ${ }^{3}$ Institute of Zoology, Poznań University of Life Sciences, Wojska Polskiego 28, 60-637 Poznań, Poland \\ ${ }^{4}$ Faculty of Environmental Sciences, Czech University of Life Sciences Prague, Kamýcká 129, 16500 \\ Prague 6, Czech Republic \\ ${ }^{5}$ Cracow Caving Club, Narzymskiego 5/2, 31-463 Kraków, Poland \\ *Corresponding author: wegiel@up.poznan.pl
}

\begin{abstract}
Bats are particularly susceptible to environmental changes because of their low reproductive rate, longevity, and high metabolic rates, which lead to relatively high food requirements. Thus, bat populations take a relatively long time to recover from increased mortality rates, and monitoring schemes should cover long time periods. In this work we analyzed the population trajectories of two bat species, Rhinolophus hipposideros and Myotis myotis, the most numerous in five caves in southern Poland, which are known as important bat hibernacula on a continental scale. Data were collected by regular counts in 1985-2001, depending on the particular cave; in addition, previous data on the number of hibernating bats in these caves, available since 1951, were taken from existing publications. We analyzed time-series data using average locality indices and TRIM methods, and both produced similar results. Generally, the populations of the two studied bat species showed recent increasing trends, especially visible as an effect of recovery after years of decline. The situation recorded in southern Poland is very similar to that described in other places in Europe, where recoveries of bat populations have also been observed in the last decades. Although it is difficult to present results from formal analyses, because of the lack of good data, at least some factorsless exposure to contaminants (pesticides, heavy metals), improving food availability due to climate change, and a lower predation rate (including human pressure), both in the breeding season and during wintering-positively affected both species.
\end{abstract}

\section{Introduction}

Bats are particularly susceptible to environmental changes because of their low reproductive rate, longevity, and high metabolic rates, which lead to relatively high food requirements ${ }^{1}$. Thus, bat populations take a relatively long time to recover from increased mortality rates ${ }^{2,3}$. Moreover, bat populations show responses to environmental stressors, ranging from alterations in habitat quality to climate change, as well as direct 
exploitation ${ }^{4-6}$, and bats are thus recognized as excellent indicators of anthropogenic changes in the environment ${ }^{7-9}$.

Important for methodological, statistical and conservation purposes are the existing long-term series, coming mainly from winter bat censuses, especially in caves ${ }^{10,11}$. For example, bats have been counted since 1944 in the Schenkgroeve, an artificial limestone cave in south Limburg in the Netherlands ${ }^{12}$, since 1946 in Hermann's cave in Lower Austria ${ }^{13}$, and since 1957 in some caves in the Moravian Karst, Czech Republic ${ }^{14}$. Thanks to the results obtained, it was discovered that European bat populations, particularly the lesser horseshoe bat Rhinolophus hipposideros and the greater mouseeared bat Myotis myotis, declined dramatically in the second half of the 20th century ${ }^{15-18 .}$ After the period of decline, since the 1990s bat populations have begun to recover ${ }^{19}$. An increase in the number of some species of hibernating bats has been reported from many European countries: Austria13, Belgium ${ }^{20}$, the Czech Republic ${ }^{21,22}$, the $\mathrm{UK}^{23}$, Italy ${ }^{24}$, Ireland ${ }^{25}$, the Netherlands ${ }^{12}$, Poland ${ }^{26}$, Slovakia ${ }^{18}$, Spain $^{27}$, Sweden $^{28}$ and Switzerland ${ }^{17}$.

The reasons for these changes in population trends have not been conclusively identified 17,29-31. It is believed that the bat population declines and subsequent increases may be caused by a combination of various factors, such as the spread of chemical pollutants, habitat destruction, changes in landscape structure, disturbance and destruction of roost sites, climate change, declines in insect prey, competition for prey, genetic inbreeding, and diseases ${ }^{17,19,32-34}$.

Both species selected for this study, the lesser horseshoe bat Rhinolophus hipposideros (hereafter: RHH) and the greater mouse-eared bat Myotis myotis (MYM) have similar preferences for shelters. In winter both species hibernate in caves, mines and other cave-like structures. They prefer places with high humidity (over 80\%) and stable temperatures of $6-9^{\circ} \mathrm{C}$. In summer the females form maternity colonies in caves (Southern Europe) or in buildings with spacious roofs such as church attics and castles (Central Europe), where they give birth and nurse their offspring ${ }^{35-37}$. Both species are insectivorous, but they differ slightly in their manner of foraging and their diet. RHH forages exclusively in woodlands, preferentially in dense areas, capturing its prey using echolocation in flight. It preys mainly on moths and Diptera. MYM preys on large, grounddwelling arthropods such as beetles, crickets, and spiders, gleaning them from the ground 38,39 . The two species are the most numerous hibernating species in the caves of 
southern Poland, an important hibernaculum on a European scale $11,16,40$. These species are excellent for monitoring population trends, as they are easy to recognize and are relatively easy to count, because they do not hide in crevices ${ }^{37,39}$.

The aim of the study was to determine long-term population trends of the lesser horseshoe bat and the greater mouse-eared bat and the probable causes of changes in the numbers of hibernating bats of these two species.

\section{Results}

\section{Population size}

The detected number of individual bats between 1950 and 2020 was very variable. The lesser horseshoe bat reached its highest number in 2020 (the last year of observation). A total of 1050 individuals were found in the five studied caves. In four caves the highest number of individuals was observed in the years 2018-2020, although in the Racławicka cave the maximum was recorded in 1950. The greater mouse-eared bat reached its highest numbers in 2016: a total of 112 individuals were found in all five caves. In particular caves the maximum number of individuals was observed in the years 20092020.

\section{Analysis based on average locality indices}

For both species the $\beta$-coefficients for linear and quadratic functions were significant (Table 1). However, for both species a lack-of-fit test showed that a quadratic function was better than a linear one (Table 1). Calculation of the extreme point of the function for the lesser horseshoe bat showed that the population decreased up to the year 1979, after which it increased (Fig. 1). In the case of the greater mouse-eared bat, the extreme point occurred in 1980 (Fig. 1). We did not find any significant differences between the two values (chi-square $=0.98, \mathrm{p}=0.86)$.

\begin{tabular}{crllll}
\hline $\begin{array}{c}\text { Bat } \\
\text { species }\end{array}$ & Function & \multicolumn{1}{c}{$\beta \pm \mathrm{SE}$} & \multicolumn{1}{c}{$p$ for $\beta$} & $\mathrm{R}^{2}$ & \multicolumn{1}{c}{ Lak-of-fit } \\
\hline \multirow{2}{*}{ RHH } & linear & $0.041 \pm 0.0075$ & $<0.01$ & 0.38 & \multirow{2}{*}{$\mathrm{F}=299.5, \mathrm{p}<0.0001$} \\
& quadratic & $0.0022 \pm 0.000014$ & $<0.0001$ & 0.89 & \\
MYM & linear & $0.15 \pm 0.03$ & $<0.01$ & 0.32 & $\mathrm{~F}=243.8, \mathrm{p}<0.0001$ \\
& quadratic & $0.0094 \pm 0.00055$ & $<0.0001$ & 0.90 & \\
\hline
\end{tabular}

Table 1. Comparing the directional factor $(\beta)$ for a population trends (RHH - lesser horseshoe bat, MYM - greater mouse-eared bat) between a linear and a quadratic function. 

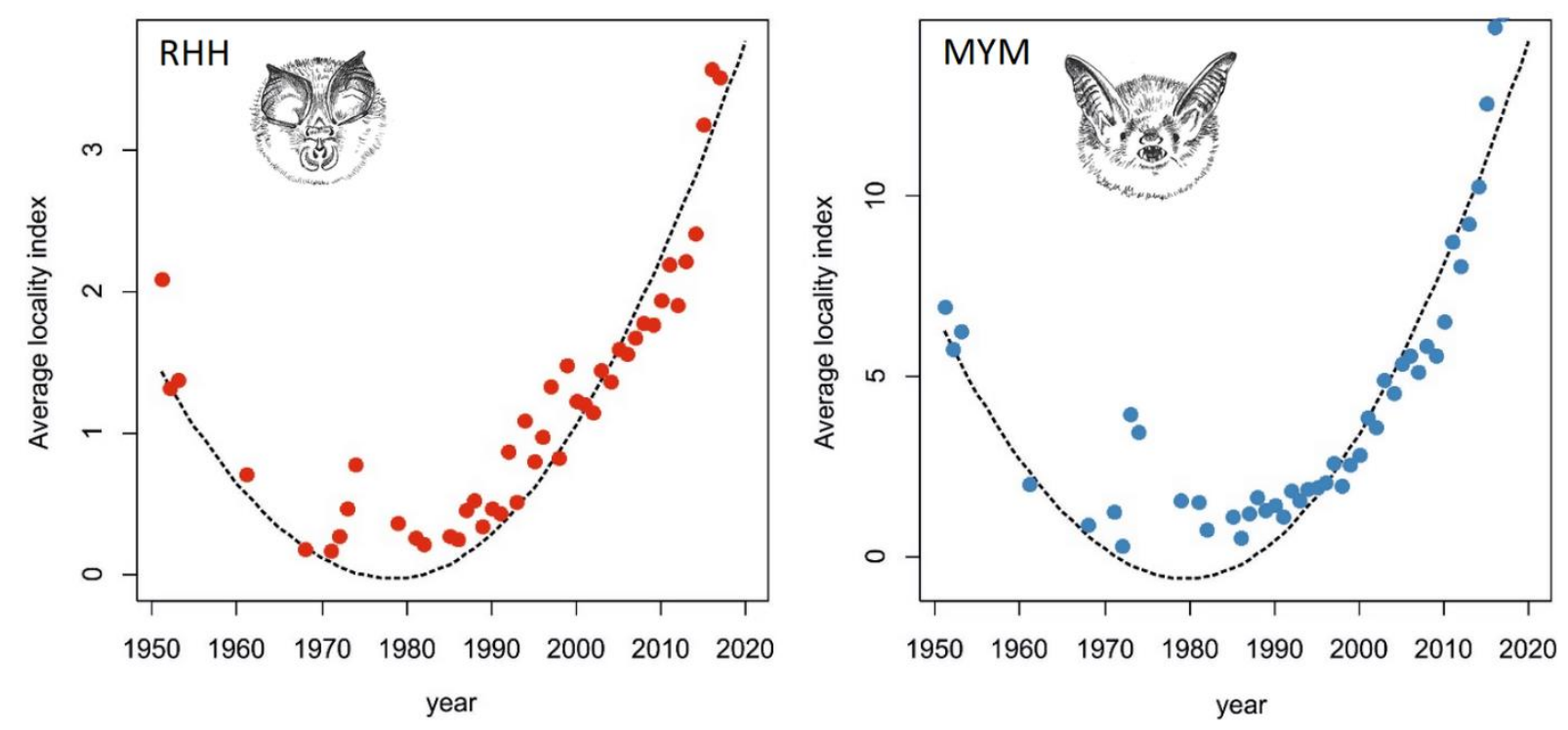

Figure 1. Average locality index (ALI) with quadratic regression for the lesser horseshoe bat (RHH) and the greater mouse-eared bat (MYM).

\section{TRIM}

All of the tests showed the same slope for both species. RHH and MYM are stable and show a moderate increase. Models using the five caves as covariates have higher AIC, smaller Wald statistics and higher standard deviation than models without them (Table 2). The goodness-of-fit tests for both species are significant. The overall slope of the linear trend model for RHH and MYM represents a moderate increase. The indices show a sharp drop in the years 1950-1973; thereafter the indices are stable again until 2001. The early increase in 2002 was mainly driven by the population dynamics in the Ciemna and Wierzchowska caves. The imputed overall index for 2010 is equal to the index from 1951 (Fig. 2).

The overall slope of the linear trend model for MYM shows an increase $(p<0.01)$. The indices show a negative trend between 1951 and 1953, followed by a moderate increase to 1981. The first peak of the increase in 1991 is mainly driven by the population dynamics in the Nietoperzowa cave.

Despite the differences between the species, their numbers (expressed as a TRIM index of year-to-year changes) were moderately correlated (Fig. 3). We also found a positive relationship between the average annual temperature and the numerical change in the TRIM index for both species, while no such significant relationship was found for precipitation or the number of days with rainfall in a particular year (Fig. 3). 


\begin{tabular}{clllll}
\hline Bat species & Covariates & AIC & $\begin{array}{l}\text { Wald-test } \\
\text { covariates }\end{array}$ & Mean SE & Goodness-of-fit \\
\hline \multirow{2}{*}{ RHH } & Only time effect & 1724.6 & - & 0.093 & $\mathrm{P}<0.001$ \\
& 5 caves & 1989.2 & $3.4, \mathrm{p}=0.48$ & 0.459 & n.s \\
\hline \multirow{2}{*}{ MYM } & Only time effect & 297.7 & - & 0.113 & $\mathrm{P}<0.001$ \\
& 5 caves & 435.3 & $2.1, \mathrm{p}=0.57$ & 0.243 & n.s \\
\hline
\end{tabular}

Table 2. Test statistics for the different TRIM models for RHH (the lesser horseshoe bat) and MYM (the greater mouse-eared bat).

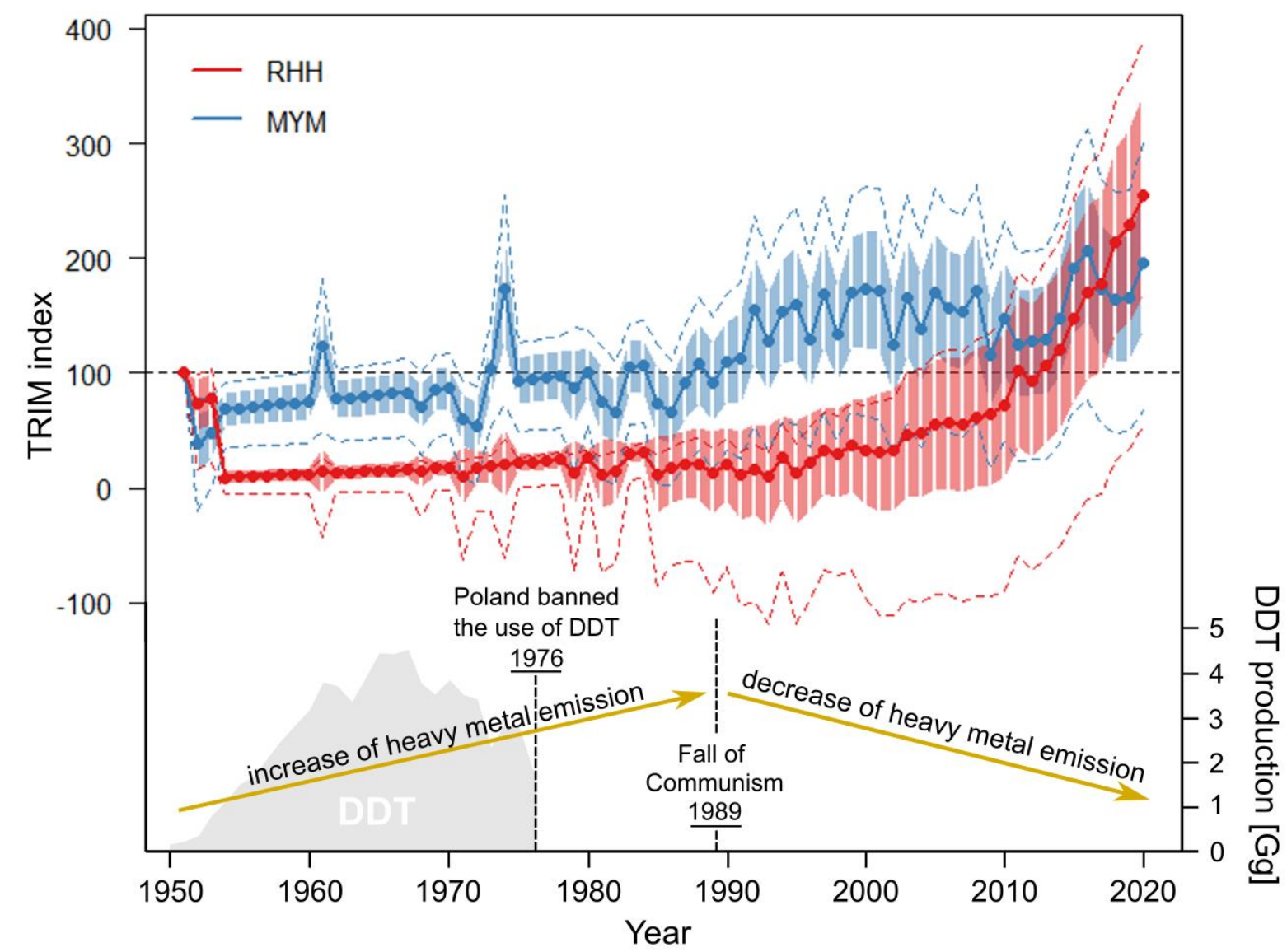

Figure 2. Changes in relative abundance according to TRIM models for the lesser horseshoe bat (RHH) and the greater mouse-eared bat (MYM). Bottom part: DDT production in Poland and trends in heavy metal emissions. 


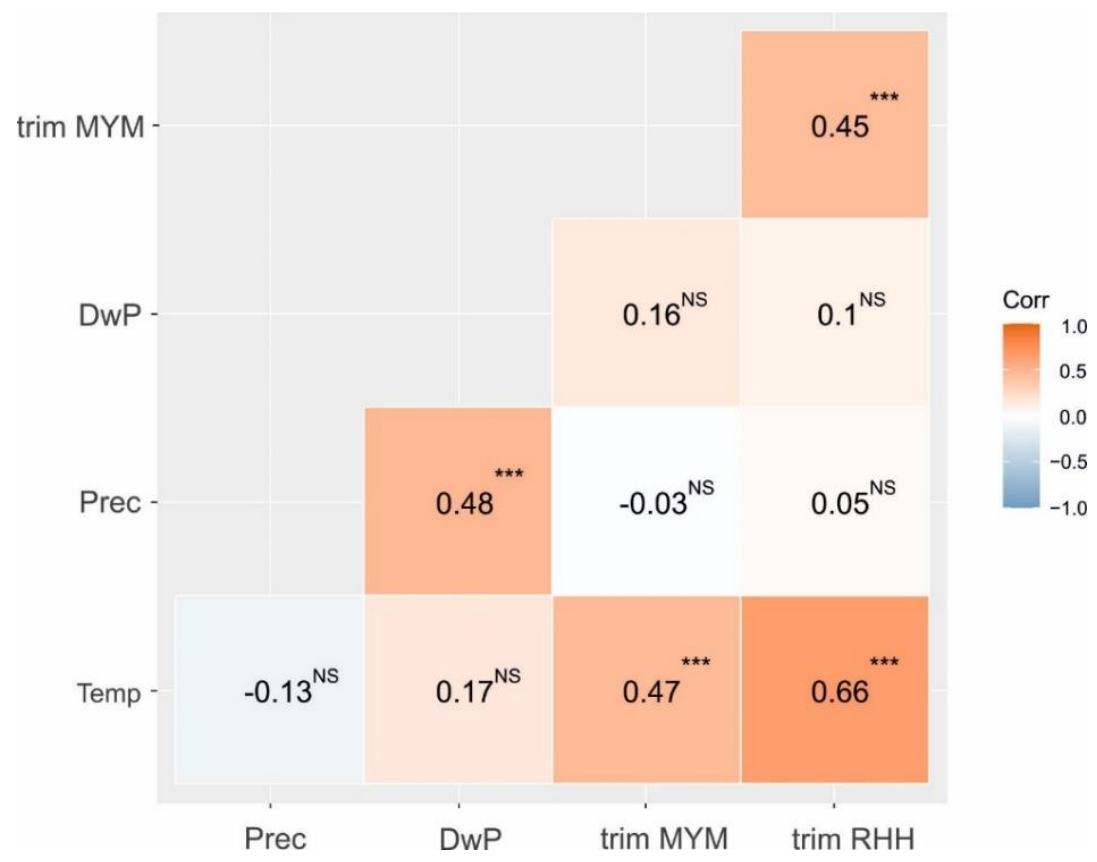

Figure 3. Correlation matrix between the TRIM index of year-to-year changes in the number of bats for the lesser horseshoe bat (trim RHH) and the greater mouse-eared bat (trim MYM) and weather conditions: average annual temperature (Temp), total precipitation (Prec) and number of days with rainfall (DwP) in particular years.

\section{Discussion}

Both analytical methods produce similar results: a recent increase in population size, and an especially visible effect of recovery after years of decline. The situation is very similar to that described in other places in Europe, where recoveries of bat populations in the last decades have been reported ${ }^{19}$. Below we discuss a set of potential factors that may have affected local bat populations, also paying attention to potential limitations in the explanation of population trajectories.

Exposure to organochlorine insecticides, especially DDT (dichlorodiphenyltrichloroethane), has been identified as a possible cause of declining bat populations ${ }^{41-43}$. DDT was used ubiquitously for pest control in agriculture and forestry in Poland in the years 1946-1976, but since then the amount of DDT in the environment has been systematically decreasing 44,45 . However, due to their relatively long lifetime and their high daily food intake, insectivorous bats may be exposed to higher concentrations of cumulative chemicals such as heavy metals, which accumulate through the food chain ${ }^{9,46}$.

The caves studied are located between the Kraków agglomeration and the Upper Silesia industrial region, where there are hundreds of industrial facilities (metallurgical 
works, chemical and cement plants, power stations). In the last decades of the 20th century, this region was the most polluted in Poland and one of the most polluted in Europe $^{47}$. As a result of the political and economic transformations in Poland at the end of the 1980s, industrial production, including that of heavy metals, declined considerably.

The area where the caves are located has not changed significantly since World War II. For both studied species the availability of woodlands (foraging areas) is crucial $^{38,39}$. However, the absence of significant changes in land use, particularly reduction in forest cover, indicates that changes in the physical (vertical) structure of habitats could not have been the main reason for the long-term changes in bat populations.

Both studied bat species (R. hipposideros and M. myotis) have similar preferences for winter and summer roosts ${ }^{37}$. In winter, bats hibernate mostly in caves and other underground places. In the Polish Jura, the number of caves available for bats has not changed noticeably in the 20 th and 21 st $^{\text {centuries }}{ }^{48}$. In the caves we monitored, the conditions of hibernation have not changed since the early $1950 \mathrm{~s}^{49}$. The summer roosts in this area are not well recognized and have not been monitored. However, there is no information about a significant number of building renovations that might have caused the loss of summer bat colonies.

We found a significant positive correlation between the population trend of both species (RHH and MYM) and the average annual temperature in 1951-2020, but we did not find such a correlation with precipitation or with the number of days with rainfall in particular years (Fig. 3). Numerous earlier studies have demonstrated the impact of climatic conditions on the activity, survival, and reproductive success of bats ${ }^{50}$. Climate influences food availability 51,52 , timing of hibernation ${ }^{53,54}$, frequency and duration of torpor 55 , rate of energy expenditure ${ }^{33,36}$, reproduction and the development rates of juveniles ${ }^{56-58}$. Global warming may influence the species richness and distribution of bats 59,60 . However, there are few studies showing the impact of temperature on bat population trends. Froidevaux, et al. ${ }^{29}$ found that the annual growth rate of maternity colonies of the greater horseshoe bat (Rhinolophus ferrumequinum) in the United Kingdom was strongly correlated with spring temperatures and precipitation. Jones and Rebelo 54 believed it highly likely that warmer conditions have contributed to considerable increases in abundance since 1997 for two species of horseshoe bats (R. ferrumequinum and $R$. hipposideros). Zahn, et al. ${ }^{33}$ compared the impact of severe 
weather in Portugal and Germany on the body condition of M. myotis. They concluded that foraging constraints due to severe weather may contribute to poor body conditions, even when food resources are abundant. Thus, bouts of bad weather may cause high mortality in bats. On the other hand, Bowler, et al. 61 emphasized that none of the temperature variables showed a significant relationship with long-term bat population trends. Mehr, et al. ${ }^{62}$ found that land use had a much greater effect than climate on bat species richness and community composition on a regional scale.

Our finding that long-term trends in bat populations were correlated with average annual temperature does not necessarily mean that temperature was the only factor affecting bat population changes. The correlation may be accidental, resulting from comparing two growing trends at the same time. Both studied bat species are thermophilic, which may be a reason for the effect of increasing temperature ${ }^{37}$, and can benefit from warming. However, temperature does not explain the decreasing trends between 1950 and 1980. Bontadina, et al. 17 also suggested that the fact that $R$. hipposideros was an abundant species early this century, when the climate was not significantly warmer than today, contradicts the scenario of a large thermic dependence as a single influencing factor.

We have no information on food availability for bats on a local scale. However, Przybyłowicz and Buszko ${ }^{63}$ observed that in the last few dozen years, the species richness of Lepidoptera in the Ojców National Park has decreased. On the other hand, monitoring of forest tree pests (insects) suggested that the most important insect pests have a tendency to outbreak in forests ${ }^{64}$. In the vicinity of the study area the only tree pest whose numbers increased was the pine sawfly (Acantholyda posticalis), and in the years 19712018 the fluctuations in its numbers were very small65. There is no information supporting the hypothesis that a shortage of insects could be the main cause of bat population changes. In Switzerland, Bontadina, et al. 66 found that changes in prey abundance are unlikely to explain the demography of the lesser horseshoe bat. However, the same factors that affected bat numbers may also have affected the number of insects.

Bats have been considered to have a particularly effective immune system, but numerous bacteria and viruses apparently remain non-pathogenic in bats, likely due to a long process of co-evolution ${ }^{67}$. Although bacterial, viral and parasitic infections may be among the main causes of bat deaths, no mass mortality from epidemics has been observed in Europe ${ }^{68}$. There is very little information about bat diseases in Poland. No 
mass mortality of bats or visible disease symptoms were observed in the caves of the Polish Jura during the winter censuses. We believe that diseases were not the main cause of long-term changes in bat numbers, but bats affected by other factors such as pollution may have been more susceptible to infection.

Temperate zone bats face a very low risk of predation. In particular, there are no predators specialized on bats in Europe ${ }^{69}$. Owls are the only nocturnal predators that can prey on bats in flight, but this is a rare and opportunistic phenomenon, and only two species of European owls, the barn owl Tyto alba and the tawny owl Strix aluco, feed on bats more frequently ${ }^{70}$. Occasionally, bats in roosts may be killed by domestic cats ${ }^{71}$ and martens ${ }^{72}$. Predation is therefore a marginal factor with little impact on bat mortality.

On the other hand, the Ojców National Park is exposed to relatively high tourist pressure, due to its small area (2146 ha), attractiveness, and location close to the city of Kraków. This pressure can be estimated on the basis of the number of visitors to the Łokietka Cave, one of the Park's greatest attractions. Sales of tickets to this cave have been recorded since 1960. There is no visible trend in the number of visitors. The current number of visitors (120 thousand in 2019) is close to the average for the whole period and to that of the early 1960s. The cave is only visited outside the bat hibernation season. Despite the high human pressure, no deliberate killing or disturbance of bats has been recorded in the caves of the Polish Jura.

Both studied species showed positive trends in population size over the long time period (1951-2020). Because the study has a correlational character, and because there was no access to detailed spatial and temporal environmental (and other) data, we discuss the main potential factors affecting both bat species according to the proposal of Bontadina, et al. ${ }^{17}$, and we rank their influence (Table 3).

\begin{tabular}{cllcc}
\hline No. & Factor & $\begin{array}{l}\text { Method of } \\
\text { assessment }\end{array}$ & $\begin{array}{l}\text { Relevance of the } \\
\text { assessment }\end{array}$ & $\begin{array}{l}\text { Assessment of } \\
\text { the importance } \\
\text { of the factor }\end{array}$ \\
\hline 1 & $\begin{array}{l}\text { Exposure to contaminants } \\
\text { (pesticides, heavy metals) }\end{array}$ & $\begin{array}{l}\text { data-based } \\
\text { assessment }\end{array}$ & high & +++ \\
\hline 2 & $\begin{array}{l}\text { Changes in the physical structure } \\
\text { of habitats }\end{array}$ & $\begin{array}{l}\text { data-based } \\
\text { assessment }\end{array}$ & high & - \\
\hline 3 & $\begin{array}{l}\text { Loss of roosts and roost } \\
\text { deterioration }\end{array}$ & expert evaluation & medium & ++ \\
\hline 4 & Climate changes & statistical analysis & high & + \\
\hline 5 & Food shortage & $\begin{array}{l}\text { data-based } \\
\text { assessment }\end{array}$ & medium & - \\
\hline 6 & Competition against other species & expert evaluation & medium & - \\
\hline 7 & Genetic inbreeding & expert evaluation & low & \\
\hline
\end{tabular}




\begin{tabular}{cllcc}
\hline 8 & Diseases & expert evaluation & low & + \\
\hline 9 & $\begin{array}{l}\text { Predation, including human } \\
\text { disturbance }\end{array}$ & expert evaluation & medium & - \\
\hline
\end{tabular}

Table 3. Assessment of factors that may have caused changes in long-term population trends of the lesser horseshoe bat and the greater mouse-eared bat. List of factors after Bontadina, et al. ${ }^{17}$. Factor assessment: “+++" - most important factor, “++" - might be important, "+" - might play some role, "-“ - not relevant.

\section{Conclusions}

Both studied species, the lesser horseshoe bat and the greater mouse-eared bat, have shown a significant increase in wintering population size over the last 70 years. We noted two directions of change: until the 1980s the population of both species was decreasing, and after that time it was increasing. Similar trends have been observed throughout Europe $^{19}$.

Although the search for factors affecting population size has only a correlative character, we must note that reduced exposure to contamination was probably the most important factor in the long-term changes in the populations of both of these bat species. However, other factors, including climate change, food shortage and diseases, may also play some role in changes in bat populations.

\section{Material and methods}

\section{Study area}

The five studied caves (Table 4) are located in the Kraków-Częstochowa Upland (also known as the Polish Jura) in the southern part of Poland (Fig. 4). The upland has elevations between 300 and $513 \mathrm{~m}$ a.s.l. The area is formed by upper Jurassic limestone, which creates a plate with single inselbergs several meters in height. This region is characterized by karst processes with numerous deep gorges, sinkholes, and caves ${ }^{73}$. Over 1800 caves and rock shelters of total length over $31 \mathrm{~km}$ are known in this area. Most of them are small: only 150 caves exceed a length of $40 \mathrm{~m}^{48} .20 \%$ of the region is covered by forests, dominated by deciduous and mixed types.

\begin{tabular}{llcccc}
\hline No & Cave & $\begin{array}{c}\text { Length }^{1} \\
(\mathrm{~m})\end{array}$ & $\begin{array}{c}\text { Relative height } \\
(\mathrm{m})\end{array}$ & $\begin{array}{c}\text { Altitude } \\
(\mathrm{m} \text { a.s.l.) }\end{array}$ & Protection \\
\hline 1 & Racławicka & 165 & -26 & 446 & - \\
\hline 2 & Nietoperzowa & 337 & -23 & 447 & $\mathrm{G}$ \\
\hline
\end{tabular}




\begin{tabular}{llcccc}
\hline 3 & Łokietka & 320 & -7 & 453 & NP, G \\
\hline 4 & Ciemna & 209 & +10 & 372 & NP, G \\
\hline 5 & Wierzchowska Górna & 975 & -25 & 390 & G \\
\hline
\end{tabular}

Table 4. Characteristics of the studied caves (NP - cave located in the national park, G - gate at the entrance).

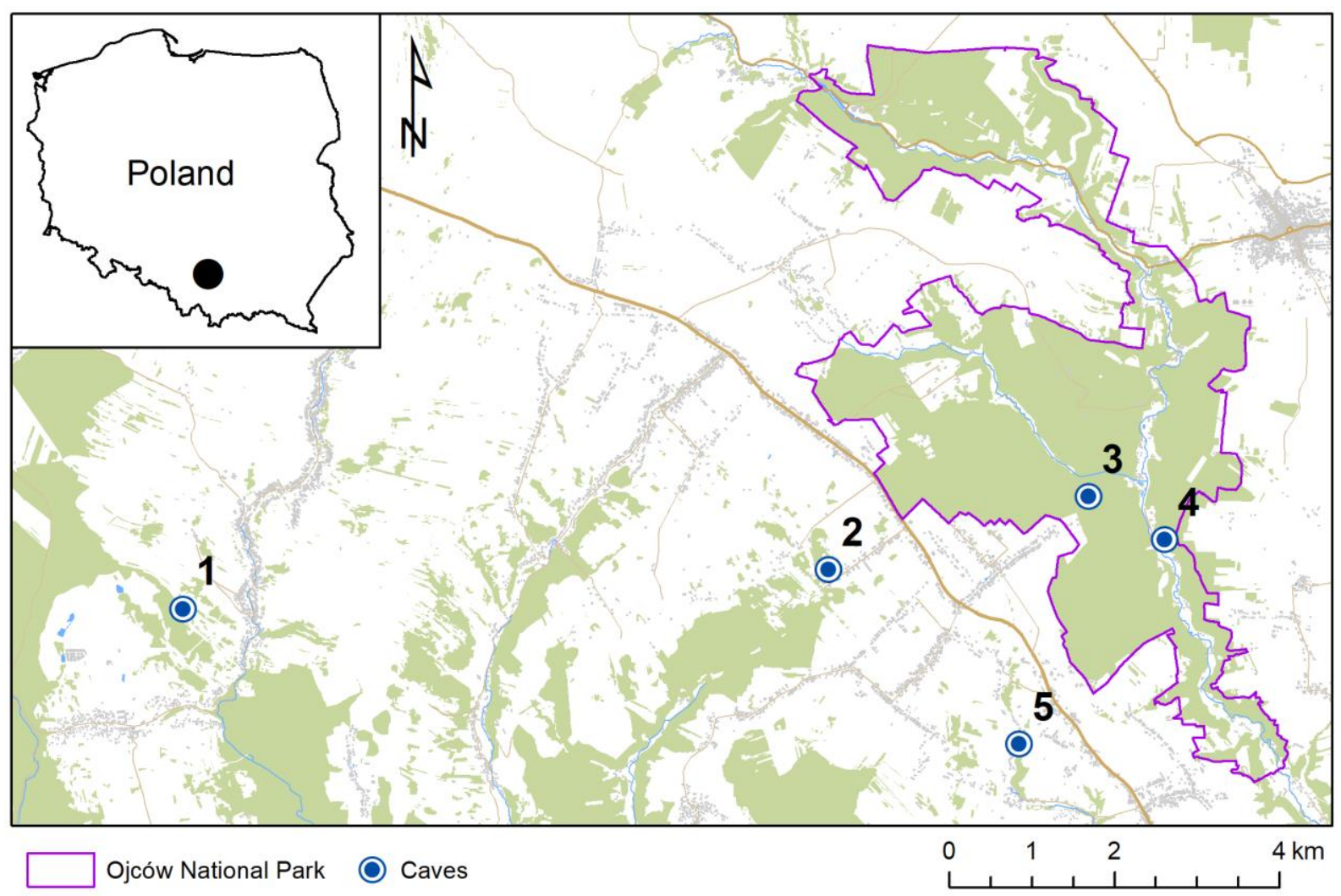

Figure 4. Location of the studied caves: 1 - Racławicka, 2 - Nietoperzowa, 3 - Łokietka, 4 Ciemna, and 5 - Wierzchowska Górna (source of spatial data: OpenStreetMap.org).

\section{Data collection}

Standardized and regular annual censuses during the hibernation period (in the first half of February) have been conducted in the caves since 1985 (Nietoperzowa and Ciemna), 1991 (Łokietka), 2000 (Racławicka) and 2001 (Wierzchowska Górna). All bats roosting in the caves are counted. The counting protocol includes visual species determination and counts of visible hibernating bats with the aid of torches and binoculars. The persons who carried out winter bat censuses had required permissions from the Minister of Environmental Protection and the Ojców National Park Director. The last permission number is DOP-WPN.436.288.2019.MŚ. Previous data on the number of hibernating bats in these caves, available from 1951, were taken from existing publications ${ }^{40,49,74-77}$. 
Climate data for the years 1951-2019-average annual temperature $\left({ }^{\circ} \mathrm{C}\right)$, total precipitation $(\mathrm{mm})$, number of days with rainfall-were obtained from the nearest meteorological station in Kraków (20 km to the south).

\section{Data analysis}

\section{Average locality index (ALI)}

Following Loman and Andersson 78 and Kyek, et al. ${ }^{79}$ we calculated the average locality index (ALI), which allowed us to compare the average population changes of the two bat species over the years, even though the numbers of both species are very different. In the first step we calculated a locality index for each cave $\left(L I_{y s}\right)$ using the formula

$$
L I_{y s}=N_{y s} / \varnothing N_{s}
$$

where:

$N_{y s}$ is the number of individuals counted for each species, cave and year $\varnothing N_{S}$ is the average number counted for a particular species at a given cave

Values below 1 indicated a relatively low count of individuals, while numbers above 1 indicated a relatively high count. Then we calculated the average locality index (ALIy) in all caves for each year, using the formula

$$
A L I=\varnothing L I_{y s}
$$

which represents the overall population trend for both species. Finally, we adjusted the linear and nonlinear trend of population change over time and tested the significance of Beta coefficients using a t-test.

In the case of monotonic functions, such as a quadratic function,

$$
f(x)=a x^{2}+b x+C
$$

for each species we calculated an extreme point of the function according to the equation

$$
E=-\frac{b}{2 a}
$$

which shows up to which year the population decreased in number, and analogously, from which year the number of individuals increased.

\section{TRIM}

The ALI method does not provide test statistics significant for population change, nor does it provide standard errors and 95\% confidence limits. Thus, as a second approach to 
analysis of the population trends we used TRIM (TRends \& Indices for Monitoring data method $)^{80}$, implemented in the rtrim library for R. This procedure makes better use of the available data, especially when some data for the years are absent-a common issue in long-term time series (in our case in the years 1950-1980)—calculating standard errors and confidence limits and offering various test statistics; it also takes into account overdispersion and serial correlation of data ${ }^{80}$. TRIM is also capable of categorizing data by covariates and testing their influence on the observed changes, using Wald tests.

TRIM fits log-linear models and indices that represent the effect of change between years, which indicates the relative variation of the total population size. Two types of indices are estimated: (i) model-based indices, which are the values predicted by the model; and (ii) imputed indices, which equal the observed count if an observation is made, and the model prediction for missing counts ${ }^{80}$. Dissimilarity between the two indices reflects a mismatch between observed (i.e. imputed indices) and model predictions (i.e. model-based indices) and, therefore, a lack of fit of the statistical model applied. In the next step indices are used to estimate a mean annual change rate ${ }^{80}$. This technique has been widely employed for the analysis of temporal series in bird populations ${ }^{81-83}$ and also bat populations $18,19,24,27,29$. We developed models with and without covariates (five caves). The best-fit models were selected according to goodness-of-fit tests (the Likelihood Ratio (LR) and Chi-squared tests) and the Akaike information criterion (AIC). A significance value for a model greater than 0.05 indicates that the data fit a Poisson distribution and, therefore, that the model can be accepted. Indices, overall slope and Wald tests remain reliable in case of lack of fit ${ }^{80}$. In case of overdispersion or serial correlation (default TRIM thresholds: $>3.0$ and $>0.4$ respectively) the Wald test for the significance of slope was employed ${ }^{80}$.

All calculations were performed in the language R 4.0.2 using the stats, rtrim, psych and ggcorrplot libraries ${ }^{84}$.

\section{Data accessibility}

Dataset available on request. 


\section{References}

1 Voigt, C. C. \& Kingston, T. in Bats in the Anthropocene: conservation of bats in a changing world (eds Christian C. Voigt \& T. Kingston) 1-9 (Springer International Publishing, 2016).

2 Racey, P. A. \& Entwistle, A. C. in Reproductive biology of bats (eds Elizabeth G. Crichton \& Philip H. Krutzsch) 363-414 (Academic Press, 2000).

3 Fleischer, T., Gampe, J., Scheuerlein, A. \& Kerth, G. Rare catastrophic events drive population dynamics in a bat species with negligible senescence. Scientific Reports 7 , 7370, doi:10.1038/s41598-017-06392-9 (2017).

4 Russo, D. \& Ancillotto, L. Sensitivity of bats to urbanization: a review. Mammalian Biology 80, 205-212, doi:10.1016/j.mambio.2014.10.003 (2015).

5 Jung, K. \& Threlfall, C. G. in Bats in the Anthropocene: conservation of bats in a changing world (eds Christian C. Voigt \& Tigga Kingston) 13-33 (Springer International Publishing, 2016).

6 Gottfried, I. et al. Long-term changes in winter abundance of the barbastelle Barbastella barbastellus in Poland and the climate change - Are current monitoring schemes still reliable for cryophilic bat species? PLoS ONE 15, e0227912, doi:10.1371/journal.pone.0227912 (2020).

7 Jones, G., Jacobs, D. S., Kunz, T. H., Willig, M. R. \& Racey, P. A. Carpe noctem: the importance of bats as bioindicators. Endangered Species Research 8, 93-115, doi:10.3354/esr00182 (2009).

8 Russo, D. \& Jones, G. Bats as bioindicators: an introduction. Mammalian Biology 80, 157-158, doi:10.1016/j.mambio.2015.03.005 (2015).

9 Zukal, J., Pikula, J. \& Bandouchova, H. Bats as bioindicators of heavy metal pollution: history and prospect. Mammalian Biology 80, 220-227, doi:10.1016/j.mambio.2015.01.001 (2015).

10 Furey, N. M. \& Racey, P. A. in Bats in the Anthropocene: conservation of bats in a changing world (eds Christian C. Voigt \& T. Kingston) 463-500 (Springer International Publishing, 2016).

11 Zukal, J., Berková, H., Band’ouchová, H., Kováčová, V. \& Pikula, J. in Cave Investigation (eds Savas Karabulut \& Mualla Çinku) (IntechOpen, 2017).

12 Grol, B. P. F. E. \& Voute, A. M. Hibernating bats in the Schenkgroeve, an artificial limestone cave in south Limburg, the Netherlands. Lutra 53, 29-46 (2010).

13 Spitzenberger, F. \& Engelberger, S. Negative trend reversal after 16 years of constant growth: The case of Rhinolophus hipposideros in an Austrian mass hibernaculum (Chiroptera: Rhinolophidae). Lynx 44, 149-156 (2013).

14 Gaisler, J., Řehák, Z. \& Zukal, J. Výzkum netopýrů v Moravském krasu: historie a současný stav [Bat research in the Moravian Karst: its history and present state]. Vespertilio 9-10, 75-85 (2006).

15 Stebbings, R. E. Conservation of European Bats. (Christopher Helm, 1988).

16 Řehák, Z. \& Gaisler, J. Long-term changes in the number of bats in the largest man-made hibernaculum of the Czech Republic. Acta Chiropterologica 1, 113-123 (1999). 
17 Bontadina, F. et al. The lesser horseshoe bat Rhinolophus hipposideros in Switzerland: present status and research recommendations. Le Rhinolophe 14, 69-83 (2000).

18 Uhrin, M., Benda, P., Obuch, J. \& Urban, P. Changes in abundance of hibernating bats in central Slovakia (1992-2009). Biologia 65, 349-361, doi:10.2478/s11756-010-0020-z (2010).

19 Van der Meij, T. et al. Return of the bats? A prototype indicator of trends in European bat populations in underground hibernacula. Mammalian Biology 80, 170-177, doi:10.1016/j.mambio.2014.09.004 (2015).

20 Kervyn, T., Lamotte, S., Nyssen, P. \& Verschuren, J. Major decline of bat abundance and diversity during the last 50 years in southern Belgium. Belgian Journal of Zoology 139, 124-132 (2009).

21 Bufka, L. \& Červený, J. Population increase of Rhinolophus hipposideros in the Šumava Mts. region, SW Bohemia. Vespertilio 16, 115-130 (2012).

22 Chytil, J. \& Gaisler, J. Development of the Rhinolophus hipposideros population in southern Moravia, Czech Republic. Vespertilio 16, 131-137 (2012).

23 Barlow, K. E. et al. Citizen science reveals trends in bat populations: The National Bat Monitoring Programme in Great Britain. Biological Conservation 182, 14-26, doi:10.1016/j.biocon.2014.11.022 (2015).

24 Toffoli, R. \& Calvini, M. Long term trend of an endangered bat species in north-western Italy. Folia Zoologica 68, 95-99, doi:10.25225/fozo.006.2019 (2019).

25 McAney, K. An overview of Rhinolophus hipposideros in Ireland (1994-2014). Vespertilio 17, 115-125 (2014).

26 Fuszara, E. et al. Population changes in Natterer's bat Myotis nattereri and Daubenton's bat M. daubentonii in winter roosts of central Poland. Polish Journal of Ecology 58, 769782 (2010).

27 Machado, M. C. et al. Population trends of cave-dwelling bats in the Eastern Iberian Peninsula and the effect of protecting their roosts. Acta Chiropterologica 19, 107-118 (2017).

28 Rydell, J., Eklöf, J., Fransson, H. \& Lind, S. Long-term increase in hibernating bats in Swedish mines - Effect of global warming? Acta Chiropterologica 20, 421-426, doi:10.3161/15081109ACC2018.20.2.012 (2019).

29 Froidevaux, J. S. P., Boughey, K. L., Barlow, K. E. \& Jones, G. Factors driving population recovery of the greater horseshoe bat (Rhinolophus ferrumequinum) in the UK: implications for conservation. Biodiversity and Conservation 26, 1601-1621, doi:10.1007/s10531-017-1320-1 (2017).

30 Tournant, P., Afonso, E., Roué, S., Giraudoux, P. \& Foltête, J.-C. Evaluating the effect of habitat connectivity on the distribution of lesser horseshoe bat maternity roosts using landscape graphs. Biological Conservation 164, 39-49, doi:10.1016/j.biocon.2013.04.013 (2013).

31 Afonso, E. et al. Is the lesser horseshoe bat (Rhinolophus hipposideros) exposed to causes that may have contributed to its decline? A non-invasive approach. Global Ecology and Conservation 8, 123-137, doi:10.1016/j.gecco.2016.09.002 (2016).

32 Arlettaz, R., Godat, S. \& Meyer, H. Competition for food by expanding pipistrelle bat populations (Pipistrellus pipistrellus) might contribute to the decline of lesser horseshoe 
bats (Rhinolophus hipposideros). Biological Conservation 93, 55-60, doi:10.1016/S00063207(99)00112-3 (2000).

33 Zahn, A., Rodrigues, L., Rainho, A. \& Palmeirim, J. M. Critical times of the year for Myotis myotis, a temperate zone bat: roles of climate and food resources. Acta Chiropterologica 9, 115-125 (2007).

34 Auteri, G. G. \& Knowles, L. L. Decimated little brown bats show potential for adaptive change. Scientific Reports 10, 3023, doi:10.1038/s41598-020-59797-4 (2020).

35 Berková, H., Pokorný, M. \& Zukal, J. Selection of buildings as maternity roosts by greater mouse-eared bats (Myotis myotis). Journal of Mammalogy 95, 1011-1017, doi:10.1644/13-mamm-a-102 (2014).

36 Jan, P.-L. et al. Which temporal resolution to consider when investigating the impact of climatic data on population dynamics? The case of the lesser horseshoe bat (Rhinolophus hipposideros). Oecologia 184, 749-761, doi:10.1007/s00442-017-3901-9 (2017).

37 Dietz, C., von Helversen, O. \& Nill, D. Bats of Britain, Europe and northwest Africa. 400 (A \& C Black, 2009).

38 Motte, G. \& Libois, R. Conservation of the lesser horseshoe bat (Rhinolophus hipposideros Bechstein, 1800) (Mammalia: Chiroptera) in Belgium. A case study of feeding habitat requirements. Belgian Journal of Zoology 132, 47-52 (2002).

39 Rudolph, B.-U., Liegl, A. \& Helversen, O. V. Habitat selection and activity patterns in the greater mouse-eared bat Myotis myotis. Acta Chiropterologica 11, 351-361, doi:10.3161/150811009X485585 (2009).

40 Grzywiński, W., Nowak, J., Kozakiewicz, K. \& Węgiel, A. Zimowy monitoring nietoperzy w jaskiniach Ojcowskiego Parku Narodowego [Winter bat monitoring in the caves of the Ojców National Park]. Prądnik 25, 89-104 (2015).

41 Clark, D. R., Jr., Kunz, T. H. \& Kaiser, T. E. Insecticides applied to a nursery colony of little brown bats (Myotis lucifugus): Lethal concentrations in brain tissues. Journal of Mammalogy 59, 84-91, doi:10.2307/1379877 (1978).

42 Luckens, M. M. \& Davis, W. H. Bats: Sensitivity to DDT. Science 146, 948-948, doi:10.1126/science.146.3646.948 (1964).

43 Jefferies, D. J. Organochlorine insecticide residues in British bats and their significance. Journal of Zoology 166, 245-263, doi:10.1111/j.1469-7998.1972.tb04088.x (1972).

44 Bayat, S., Geiser, F., Kristiansen, P. \& Wilson, S. C. Organic contaminants in bats: Trends and new issues. Environment International 63, 40-52, doi:10.1016/j.envint.2013.10.009 (2014).

45 Falandysz, J., Brudnowska, B., Kawano, M. \& Wakimoto, T. Polychlorinated Biphenyls and Organochlorine Pesticides in Soils from the Southern Part of Poland. Archives of Environmental Contamination and Toxicology 40, 173-178, doi:10.1007/s002440010160 (2001).

46 Hernout, B. V. et al. A national level assessment of metal contamination in bats. Environmental Pollution 214, 847-858, doi:10.1016/j.envpol.2016.04.079 (2016).

47 Dmuchowski, W. \& Bytnerowicz, A. Monitoring environmental pollution in Poland by chemical analysis of Scots pine (Pinus sylvestris L.) needles. Environmental Pollution 87, 87-104, doi:10.1016/S0269-7491(99)80012-8 (1995). 
48 Gradziński, M. \& Szelerewicz, M. Liczba i rozmieszczenie jaskiń Wyżyny KrakowskoWieluńskiej - stan obecny [Number and distribution of caves in the Kraków-Wieluń Upland - current state]. Jaskinie 3, 28-30 (2004).

49 Kowalski, K. Materiały do rozmieszczenia i ekologii nietoperzy jaskiniowych w Polsce [Materials for the distribution and ecology of cave bats in Poland]. Fragmenta Faunistica 6, 541-567 (1953).

50 Sherwin, H. A., Montgomery, W. I. \& Lundy, M. G. The impact and implications of climate change for bats. Mammal Review 43, 171-182, doi:10.1111/j.13652907.2012.00214.x (2013).

51 Ciechanowski, M., Zając, T., Biłas, A. \& Dunajski, R. Spatiotemporal variation in activity of bat species differing in hunting tactics: effects of weather, moonlight, food abundance, and structural clutter. Canadian Journal of Zoology 85, 1249-1263, doi:10.1139/z07-090 (2007).

52 Arlettaz, R., Christe, P., Lugon, A., Perrin, N. \& Vogel, P. Food availability dictates the timing of parturition in insectivorous mouse-eared bats. Oikos 95, 105-111 (2001).

53 Hope, P. R. \& Jones, G. Warming up for dinner: torpor and arousal in hibernating Natterer's bats (Myotis nattereri) studied by radio telemetry. Journal of Comparative Physiology B 182, 569-578, doi:10.1007/s00360-011-0631-x (2012).

54 Jones, G. \& Rebelo, H. in Bat evolution, ecology, and conservation (eds Rick A. Adams \& Scott C. Pedersen) 457-478 (Springer New York, 2013).

55 Stawski, C., Willis, C. K. R. \& Geiser, F. The importance of temporal heterothermy in bats. Journal of Zoology 292, 86-100, doi:10.1111/jzo.12105 (2014).

56 Adams, R. A. \& Hayes, M. A. Water availability and successful lactation by bats as related to climate change in arid regions of western North America. Journal of Animal Ecology 77, 1115-1121, doi:10.1111/j.1365-2656.2008.01447.x (2008).

57 Burles, D. W., Brigham, R. M., Ring, R. A. \& Reimchen, T. E. Influence of weather on two insectivorous bats in a temperate Pacific Northwest rainforest. Canadian Journal of Zoology 87, 132-138, doi:10.1139/z08-146 (2009).

58 Lučan, R. K., Weiser, M. \& Hanák, V. Contrasting effects of climate change on the timing of reproduction and reproductive success of a temperate insectivorous bat. Journal of Zoology 290, 151-159, doi:10.1111/jzo.12021 (2013).

$59 \mathrm{Wu}, \mathrm{J}$. Detection and attribution of the effects of climate change on bat distributions over the last 50 years. Climatic Change 134, 681-696, doi:10.1007/s10584-015-1543-7 (2016).

60 Rebelo, H., Tarroso, P. \& Jones, G. Predicted impact of climate change on European bats in relation to their biogeographic patterns. Global Change Biology 16, 561-576, doi:10.1111/j.1365-2486.2009.02021.x (2010).

61 Bowler, D. E. et al. A cross-taxon analysis of the impact of climate change on abundance trends in central Europe. Biological Conservation 187, 41-50, doi:10.1016/j.biocon.2015.03.034 (2015).

62 Mehr, M. et al. Land use is more important than climate for species richness and composition of bat assemblages on a regional scale. Mammalian Biology 76, 451-460, doi:10.1016/j.mambio.2010.09.004 (2011).

63 Przybyłowicz, Ł. \& Buszko, J. in Monograph of the Ojców National Park. Nature (eds Anna Klasa \& Józef Partyka) (Ojców National Park, 2008). 
64 Perlińska, A. \& Hamera-Dzierżanowska, A. Gradacje szkodników pierwotnych sosny w Lasach Państwowych [Outbreaks of the primary Scots pine pests in State Forests]. Studia $i$ Materiały CEPL w Rogowie 46, 32-42 (2016).

65 Sławski, M. \& Sławska, M. in Materials of the conference "Current Problems of Forest Protection", 15-17 October 2019 (2019).

66 Bontadina, F., Schmied, S. F., Beck, A. \& Arlettaz, R. Changes in prey abundance unlikely to explain the demography of a critically endangered Central European bat. Journal of Applied Ecology 45, 641-648, doi:10.1111/j.1365-2664.2007.01417.x (2008).

67 Afelt, A., Devaux, C., Serra-Cobo, J. \& Frutos, R. in Bats (ed Heimo Mikkola) (IntechOpen, 2018).

68 Mühldorfer, K. et al. Diseases and causes of death in European bats: Dynamics in disease susceptibility and infection rates. PLOS ONE 6, e29773, doi:10.1371/journal.pone.0029773 (2011).

69 Lima, S. L. \& O'Keefe, J. M. Do predators influence the behaviour of bats? Biological Reviews 88, 626-644, doi:10.1111/brv.12021 (2013).

70 Sieradzki, A. \& Mikkola, H. in Owls (ed Heimo Mikkola) (IntechOpen, 2020).

71 Ancillotto, L., Serangeli, M. T. \& Russo, D. Curiosity killed the bat: Domestic cats as bat predators. Mammalian Biology 78, 369-373, doi:10.1016/j.mambio.2013.01.003 (2013).

72 De Marinis, A. M. \& Masseti, M. Feeding habits of the pine marten Martes martes L., 1758, in Europe: a review. Hystrix 7, doi:10.4404/hystrix-7.1-2-4063 (1995).

73 Kondracki, J. Geografia regionalna Polski [Regional geography of Poland]. (PWN, 2001).

74 Harmata, W. Zmiany populacji nietoperzy (Chiroptera) w niektórych jaskiniach Wyżyny Krakowsko-Częstochowskiej w latach 1945-1979 [Changes in the population of bats (Chiroptera) in some caves of the Kraków-Częstochowa Upland between 1945 and 1979]. Rocznik Muzeum Okręgowego w Częstochowie 5, 23-30 (1981).

75 Wołoszyn, B. W. Bemerkungen zur Populationsentiwicklunk der Klainen Hufeisennase, Rhinolophus hipposideros (Bechstein, 1800) in Polen [Remarks on the population development of the Lesser horseshoe bat, Rhinolophus hipposideros (Bechstein, 1800) in Poland]. Myotis 14, 37-52 (1976).

76 Godawa, J. \& Wołoszyn, B. W. Nietoperze (Mamalia, Chiroptera) Ojcowskiego Parku Narodowego [Bats (Mamalia, Chiroptera) of Ojców National Park]. Prądnik 1, 143-148 (1990).

77 Nowak, J. \& Kozakiewicz, K. Zimowe spisy nietoperzy na Wyżynie Krakowskiej w latach 1993-1999 [Winter bat censuses in the Kraków Upland in 1993-1999]. Studia Chiropterologica 1, 43-56 (2000).

78 Loman, J. \& Andersson, G. Monitoring brown frogs Rana arvalis and Rana temporaria in 120 south Swedish ponds 1989-2005. Mixed trends in different habitats. Biological Conservation 135, 46-56, doi:10.1016/j.biocon.2006.09.017 (2007).

79 Kyek, M., Kaufmann, P. H. \& Lindner, R. Differing long term trends for two common amphibian species (Bufo bufo and Rana temporaria) in alpine landscapes of Salzburg, Austria. PLoS ONE 12, e0187148, doi:10.1371/journal.pone.0187148 (2017). 
80 Pannekoek, J. \& van Strien, A. J. Trim 3 Manual (TRends \& Indices for Monitoring data). Vol. Voorburg, The Netherlands (Statistics Netherlands, 2005).

81 Paradis, E., Baillie, S. R., Sutherland, W. J. \& Gregory, R. D. Exploring densitydependent relationships in demographic parameters in populations of birds at a large spatial scale. Oikos 97, 293-307, doi:10.1034/j.1600-0706.2002.970215.x (2002).

82 Lehikoinen, A. et al. Declining population trends of European mountain birds. Global Change Biology 25, 577-588, doi:10.1111/gcb.14522 (2019).

83 Gregory, R. D. et al. Population trends of widespread woodland birds in Europe. Ibis 149, 78-97, doi:10.1111/j.1474-919X.2007.00698.x (2007).

84 R Core Team. R: A language and environment for statistical computing. (R Foundation for Statistical Computing, 2018).

\section{Acknowledgements}

We would like to thank the participants of the winter bat censuses, in particular: Przemysław Adamus, Jolanta Cerek, Małgorzata Hoppe, Barbara Karwowska, Anna Kmiecik, Paweł Kmiecik, Katarzyna Kozakiewicz, Katarzyna Malak, Wojciech Olma, Krzysztof Polowy, Rafał Sadowy, Marta Wieczorek and Mikołaj Zbonik. We would also like to thank numerous participants of winter censuses from: Student Foresters' Club of the Poznań University of Life Sciences, Student Naturalist Society at the Jagiellonian University and Cracow Caving Club.

The publication is co-financed within the framework of the Ministry of Science and Higher Education program "Regional Initiative Excellence" in the years 2019-2022, project number 005/RID/2018/19.

\section{Author Contributions}

Conceptualization, W.G., P.T. and A.W.; investigation, W.G., J.N., A.W. and J.W.; statistical analysis, J.Z.K..; visualization, J.Z.K. and A.W.; writing-original draft preparation, A.W.; writing-review and editing, W.G., J.Z.K., P.T. and A.W. All authors wrote on the manuscript and gave final approval for publication.

\section{Additional Information}

Competing Interests: The authors declare that they have no competing interests. 
Figures
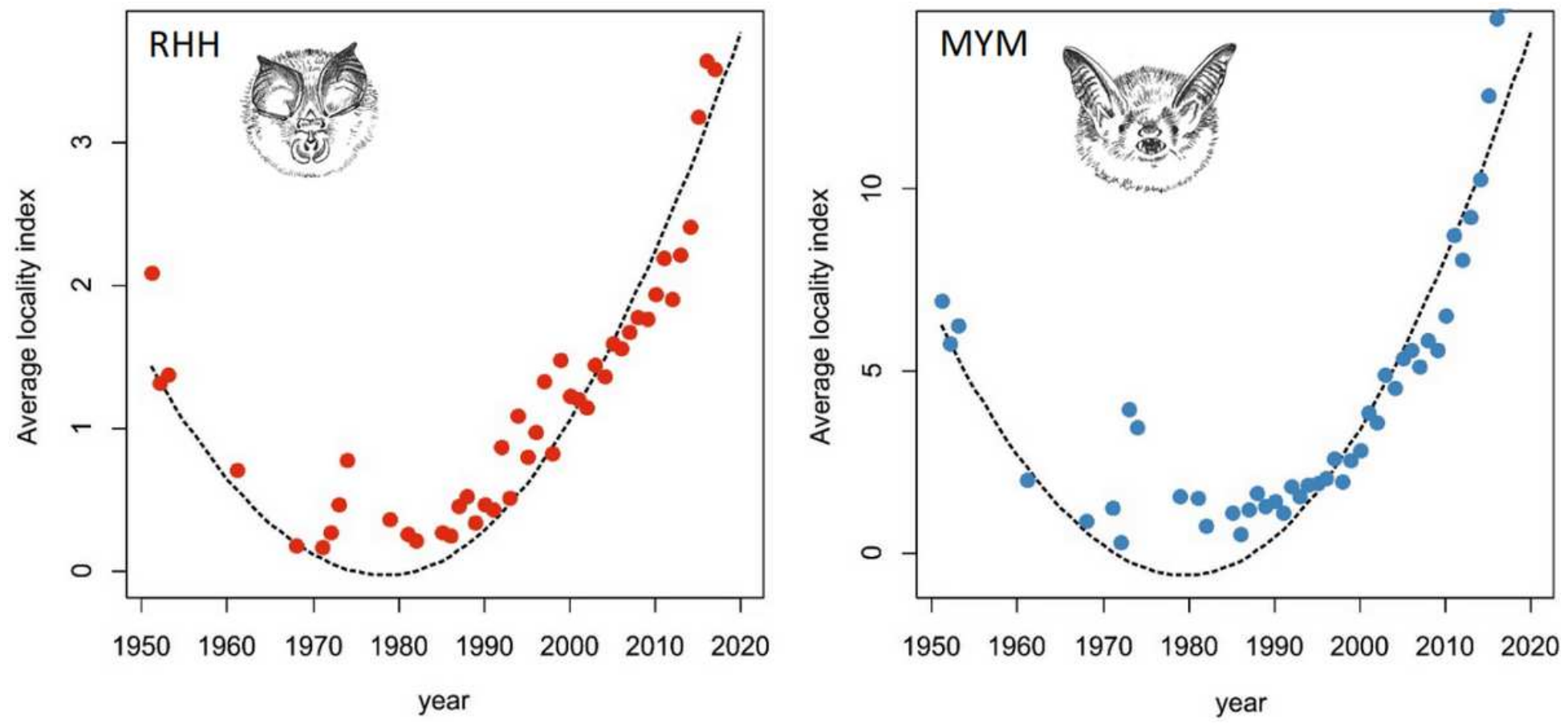

Figure 1

Average locality index (ALI) with quadratic regression for the lesser horseshoe bat $(\mathrm{RHH})$ and the greater mouse-eared bat (MYM). 


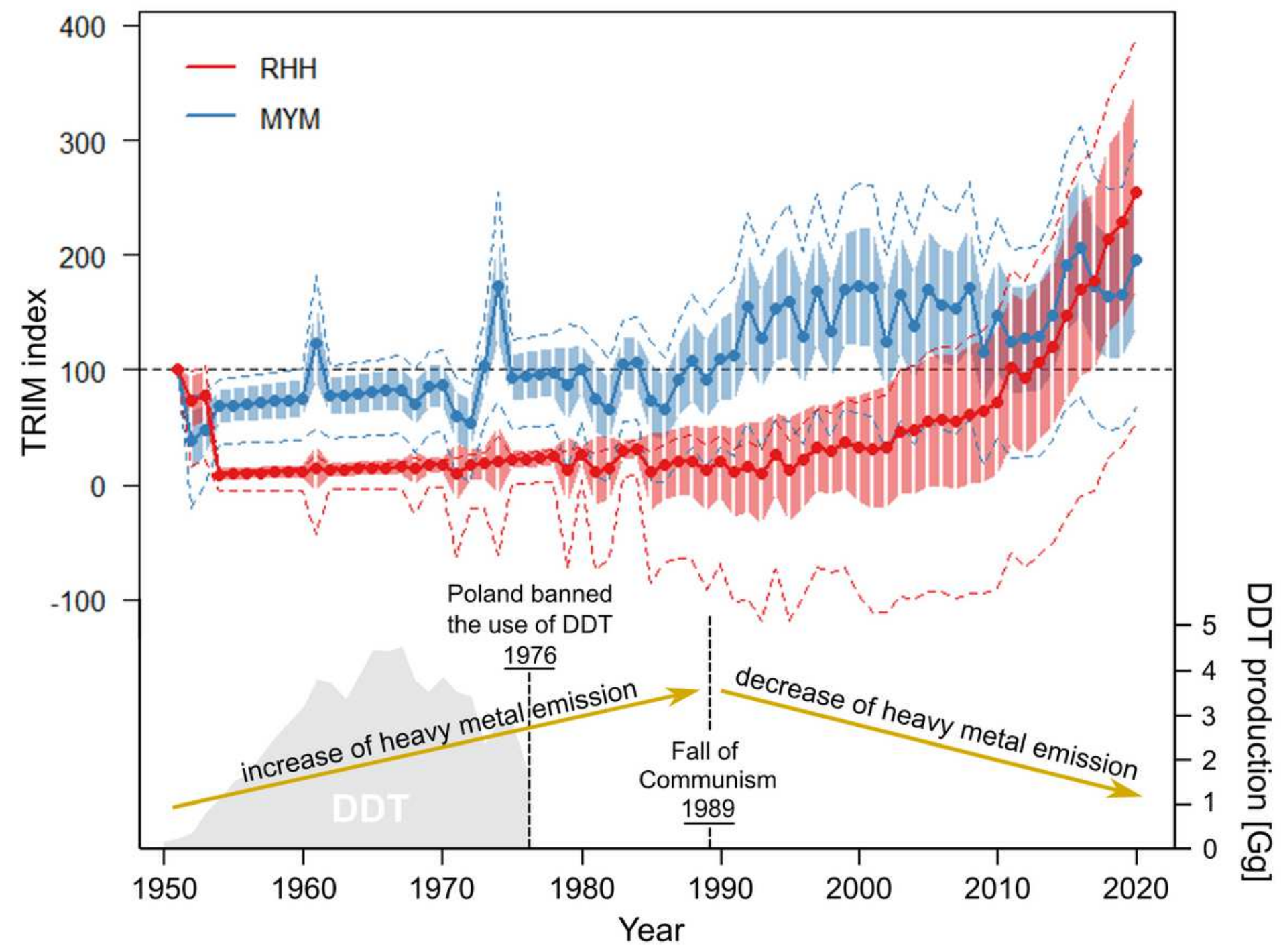

Figure 2

Changes in relative abundance according to TRIM models for the lesser horseshoe bat $(\mathrm{RHH})$ and the greater mouse-eared bat (MYM). Bottom part: DDT production in Poland and trends in heavy metal emissions. 


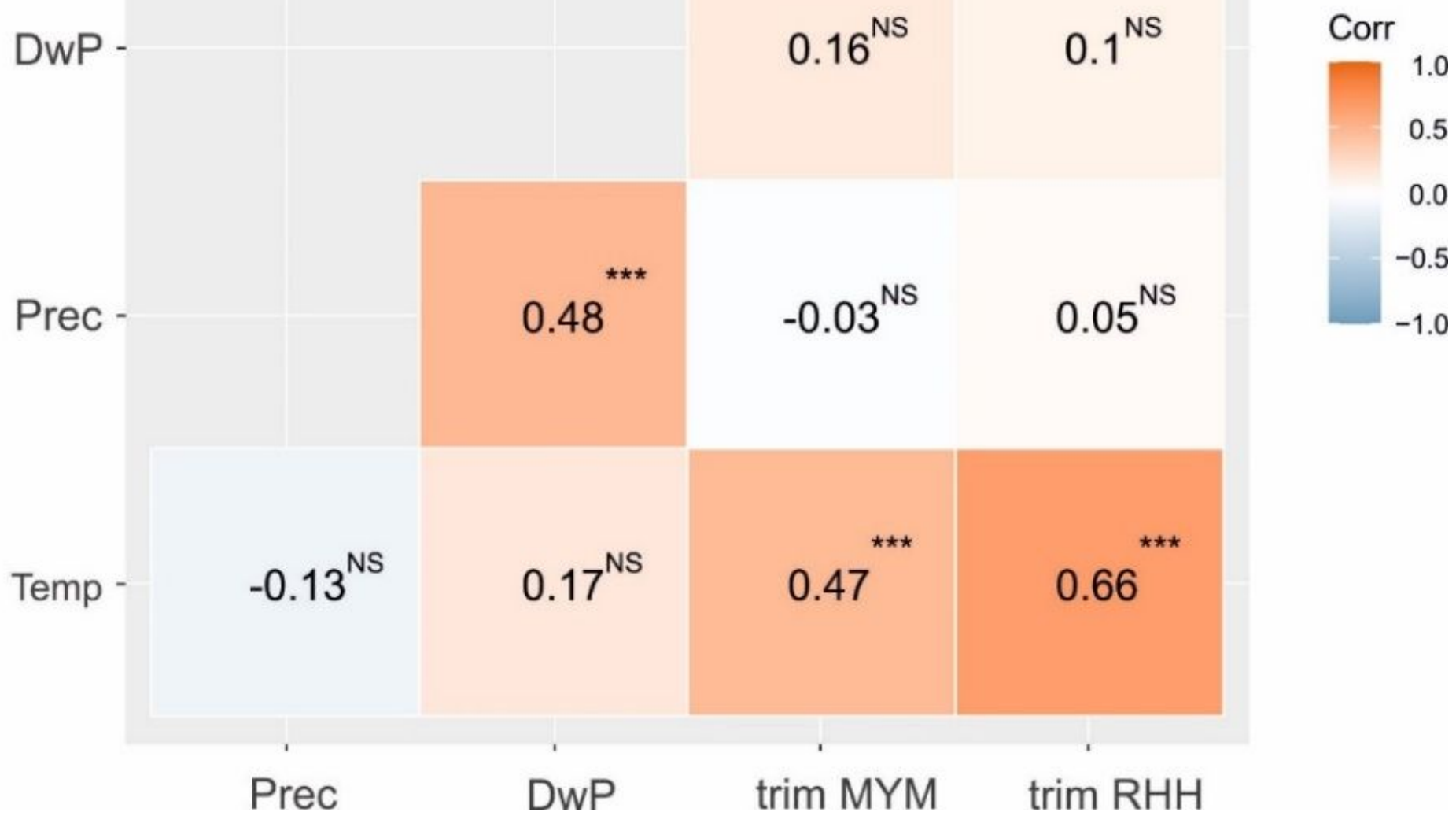

\section{Figure 3}

Correlation matrix between the TRIM index of year-to-year changes in the number of bats for the lesser horseshoe bat (trim RHH) and the greater mouse-eared bat (trim MYM) and weather conditions: average annual temperature (Temp), total precipitation (Prec) and number of days with rainfall (DwP) in particular years. 


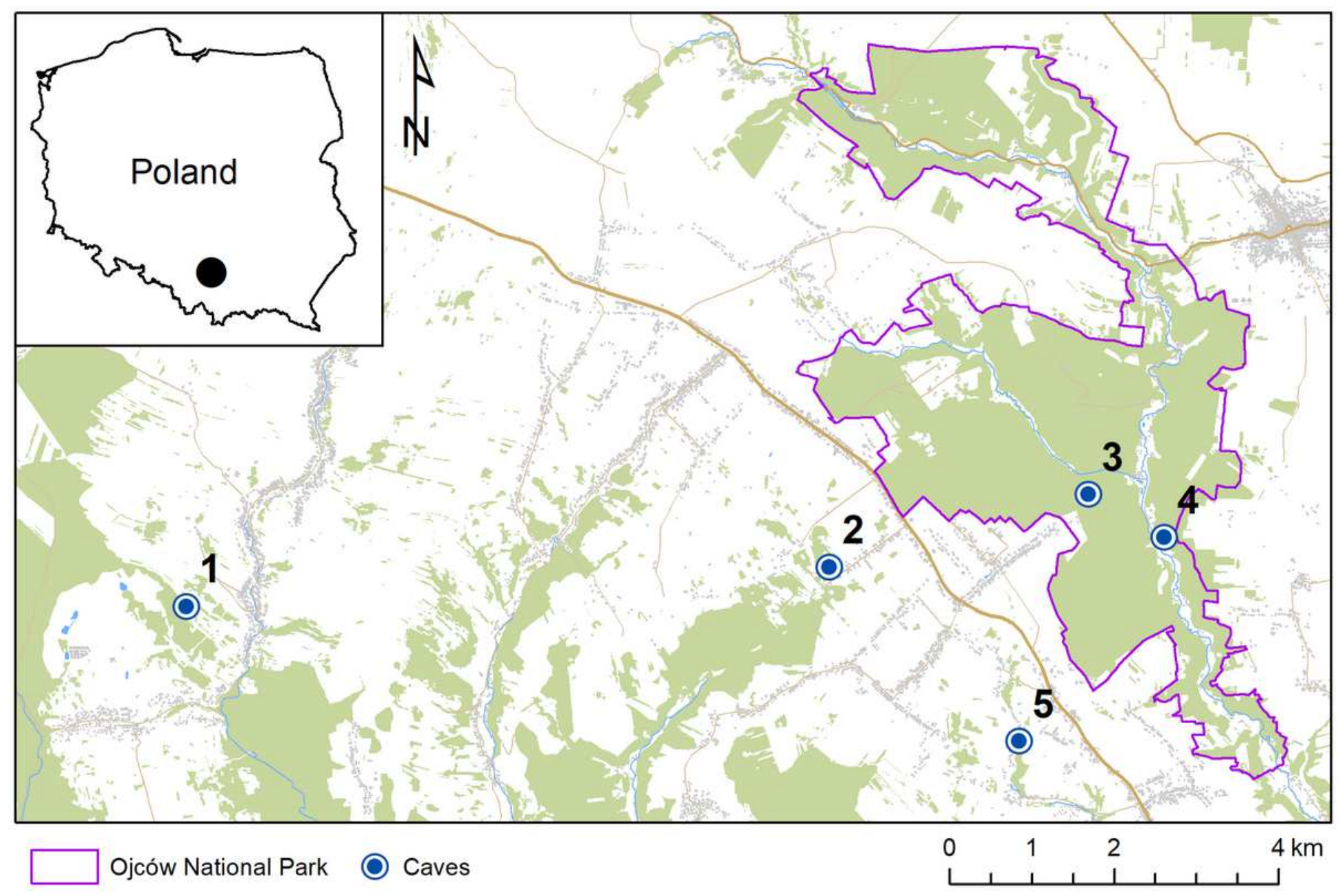

Figure 4

Location of the studied caves: 1 - Racławicka, 2 - Nietoperzowa, 3 - Łokietka, 4 - Ciemna, and 5 Wierzchowska Górna (source of spatial data: OpenStreetMap.org). 